\title{
Outsourced Property Management: The Regulations of the Property Manager
}

\author{
Peter Palm \\ Malmö university
}

\begin{abstract}
Purpose - The purpose is to identify factors on property management level for analysing incentives for an effective property management in an outsourced setting.

Design/methodology/approach - This research is based on an interview study of a set of three real estate owning companies and their contracted facility management companies property management teams.

Findings - The study conclude that the property manager within the facility management company is highly controlled by the contract between the real estate owner and the facility management company. However, this contract do risk the individual property manager to prioritise the wrong work tasks as she has to know exactly what to prioritise in each contract and consider in whose interest she perform each task, the real estate owner, her employer or the tenants.

Research limitations/implications - The research in this paper is limited to Swedish commercial real estate sector

Practical implications - The insight in the paper regarding how real estate owners creates incentives for the facility management companies property management organisation and how that is perceived by the individual property manager.

Originality/value - It provides an insight regarding how the commercial real estate industry prioritise different work tasks and how incentives are created to enable effort.

Keywords - Property Management, Outsourcing, Facility management, Incentives, Decision making, Commercial Real Estate,

Paper type Research paper
\end{abstract}

\section{Introduction}

As the real estate industry manages large values, the decisions of those who work within the industry have direct consequences on invested capital, tenants (and, indirectly, the tenants' investments) as well as the structural fabric of buildings. Traditionally, internal personnel have managed these large values and been solely responsible for the properties and their tenants. However, this has changed in recent decades, where management tasks have become increasingly specialised (Ventovuori, 2007; Lawrence, \& Poh, 1999). This specialisation during in recent times has also introduced a greater interest in using outsourcing as a management strategy. At the same time as these functions require more specialised knowledge and firms consider vertical and horizontal integration, Agerwal and Hauswald (2010) argue that one of the most growing problems in organisations is the lack of essential information in order to make informed decisions.

When working in the real estate industry, the type of information required is often soft information - information that is private, hard to quantify and difficult to compare, as it is subject to interpretation (Stein, 2002). As it is paired with the increasing specialisation of the real estate sector, the structure of the property management function also needs to be reexamined. 
The main focus of this article is the property manager's function within the facility management companies that manage commercial real estate. The aim is to identify how the property manager in the facility management company is managed and what incentives she has to perform in line with the real estate owner's requirements.

This article presents the results of an interview study with the purpose of identifying factors that create incentives in outsourced property management from a transaction cost perspective. The study aims to contribute to the body of knowledge on strategic property management.

The article is structured as follows: The next section, Section 2, presents the theoretical background. In this section, the first part will present the structure of property management, the second part discusses the question of outsourcing, the third part outlines the transaction cost approach of organisations, and the last part focuses on the incentive perspective. Section 3 presents the research design and methodology of the study. In Section 4, a description of tasks, functions and information sharing will be outlined before presenting the findings regarding the incentives for effort and information sharing, while Section 5 involves a discussion of how the real estate owner company has created incentives for efficient property management.

\section{Theoretical background}

In the 1990s, the Swedish finance and real estate crisis led the restructuring of the Swedish real estate industry. This restructuring changed the conditions for organising corporations and their business models. Similarly, it also changed the possibilities for companies to organise their value-creating activities to create competitive advantages, meaning their strategy.

Due to the amount of interest from researchers and practitioners over recent decades, the concept of strategy has been described and defined in various ways. This paper takes its theoretical standpoint in the classical approach to strategy, which views it as a rational process of well-analysed and deliberate choices. The overall aim of the process is to maximise profits and benefits over time, or as Ansoff (1984) defines it, strategy is a systematic approach for the management to position and relate the firm to its environment in a way to enable continuous success. This definition is essential when considering the organisational design of the management structure.

The concept of creating a firm's competitive advantage through an organisation's valuecreating activities was developed by Edith Penrose (1959) in the 1950s. The background was that Penrose did not find the classical economic theory of supply and demand sufficient for demonstrating the success factors for companies. Instead, she identified and exemplified productive resources, both tangible and intangible. Based on the prerequisites that Penrose (1959) presented regarding resource-based companies, it can be defined as a portfolio of value-creating resources. The management's ability to create and sustain their competitive advantage is then crucial for building and maximising long-term profit.

\subsection{Structure of property management}

Structure is a wide term in the strategy literature (see for example Johnson et al., 2011) that focuses on organisational "design". Here, structure is defined by how the industry defines responsibilities and lines of reporting in regard to customer focus in commercial real estate 
management organisations. All the different ways of structuring the organisation have different pros and cons in regard to transaction costs and the principal-agent complex. Different structures lead to different business models. A business strategy usually consists of strategies on three levels: corporate, business and functional (see for example Ali et al., 2008, Morrison and Roth, 1992, or Porter, 1981). Strategy on the corporate level is generally defined as a company's overall direction in terms its general plans for both growth and product segmentation (see for example Morrison and Roth, 1992). This indicates that the main concern of corporate strategy is to elect the areas in which the company will be present. This paper addresses the corporate real estate industry in particular and not the real estate industry in general; as a result, the more general level is left out. The level of business strategy is concerned with how the structure of the organisation matches the internal capabilities and resources of the company and its external environment (see for example Porter, 1981). Strategies on a functional level are strategies made to support those on the business level (Porter, 1981).

Caves (1980) defines strategy on the business level as focused on 'How?' rather than 'What?', just as the corporate strategy does. As the business strategy is an extension of the corporate strategy, the formulation of business strategy and the structuring of the organisation must fall in line with the company's overall plans. Edwards and Ellison (2004) state that the purpose of developing a business strategy is to focus on the operations of the company's business. It is from this that we derive the concept of business models. Teece (2010) states that there is a lack of research regarding structures of business models. This falls in line with Hewlett (1999), who states that strategic planning aims at developing a business model. One can argue that the theoretical framework is well developed within the theory of strategic planning, even if the concept of the business model is not problematised to the same extent as strategic planning or even strategic management for that matter.

The organisation's business model is to be based on its internal strengths, which are termed strategic capacity. Wernfelt's (1984) definition of strategic capacity is where both the organisation as a whole and the organisation's individual parts are valued separately. The organisation's strategic capacity is determined by the performance of its activities relating to service, marketing, delivery and the monitoring of services. According to the concept of capacity, it is the different value-creating activities of the organisation and the relationship between them which constitute its competitive advantage.

The business model of the organisation should focus on the value-creating resources in the company and how they are used within the organisation. The strategic decisions regarding the function of the organisation is situated on two levels. First, a decision must be made about whether the value activity is to be organised in-house or outsourced. Second, management must decide if the value-creating resources available in-house should be considered a separate function within the organisation or as a task, among others, within a function.

\subsection{Outsourcing}

Atkins and Brooks (2015) define outsourcing as contracting-out services that were previously performed in-house. When studying organisations, the strategic perspective of outsourcing production can be traced back to Coase's classic paper, “The nature of the Firm” (1937). He introduced the idea that the boundary of the firm was a strategic decision to an economic assessment, instead of something predestined. As a strategy, outsourcing has existed since the 1950s. However, we could see that it was only during the 1980s that it became a generalised 
strategy. The phenomenon of outsourcing stems from the strategy to outsource a function previously performed internally to an external provider, which provides the organisation with the current function during the agreed time. The concept has also increasingly come to be synonymous with a company that chooses not to conduct all of its business in-house without the help of external parties. Thus, outsourcing also equates with the strategy of purchasing services externally despite that, in certain cases, there may be services that were not previously available within the company yet are traditionally regarded as natural features within the industry.

There are two different arguments for outsourcing. The first originates from the theory of resource-based view (RBV) of the firm, which takes the view that if certain tasks are not conducted within the firm's core business, then they should be outsourced (Penrose 1959). The other argument comes from the theory of transaction costs. The theory maintains that if you can buy a service on the market at a lower price with the same quality or better than performing it yourself, then you should turn to the market (Williamson 1975).

When relating the two previous arguments the to the real estate market, one generally finds two situations when real estate owners should outsource their property management function. The first situation is when owners have their real estate holding as a capital investment, just as any other asset. Here, all insurance companies, banks, trust funds and so on also fall into this category. The second situation is when it is not rational for the owning company to have its own personnel because it owns too few properties in a specific geographical area. In this category, one can find small companies with one or two properties or large companies with a geographically diverse real estate portfolio. This is what Zuniga (2005) states as the top two key factors driving the strategy of outsourcing: flexibility and cost control.

The resource-based view of the firm and the transaction cost theory are closely connected. Williamson (1975) defines this connection on the basis that companies choose to integrate the functions of the assets (or competencies) that are specific and create value for the company. At the same time, features that are considered to be specific and value-creating for the company constitute its core business. In the real estate field, core business can be seen from different angles. Various real estate companies define their core business in different ways, some see themselves as service companies and other sees themselves as providers of a product in the form of premises (Lundström 2011). How the company chooses to define itself as a property management company or as a real estate owning company may result in identifying different functions as their core business.

In the 1990s, a distinction was created between contracting on a job-to-job basis and the outsourcing of one or more organisational functions. During the same time, it could also be observed how the concept of strategic outsourcing increased in focus (Hätönen and Eriksson, 2009). The trend was that companies did not see the phenomenon as simply short-term costcutting but rather as long-term strategic solutions which reflected its organisational structure and business model. This phenomenon became central when business models were being planned. It became even stronger when concepts such as strategic alliances emerged as key concepts when issues of outsourcing were discussed. The discussions clarified which valuecreating activities would be defined as critical to the organisation.

\subsection{Transaction costs in organisations}


Transaction costs refer to all costs incurred in a business or a service exchange. This includes costs associated with contract formation, information retrieval and dissemination, and engagement in the service exchange. Essentially, the transaction costs refer to all costs that can occur when a task should be performed. This means that transaction costs occur when a service is transferred. The transferring refers to both business dealings within the organisation and as well as those of a customer or business partner. Williamson (1981) refers to it as a machine - if it is a well-working machine, the transfer will be done smoothly. However, friction in the mechanical system is due to the economic counterpart, transaction costs. Examples of transaction costs are costs associated with writing contracts, obtaining information and engaging in exchange. However, as the transaction can include opportunistic behaviour, costs that are associated with misunderstandings, conflicts and anything else that interrupts the harmonious exchange of the service delivery to be transferred are also considered as transaction costs.

In terms of making the service delivery as smooth as possible, the contract is in focus. It is the contract that stipulates what should be done and how, but contracts are inherently incomplete. Complete contracts are not possible because all possible future contingences cannot be foreseen at all times. This emphasises the fact that everyone acts under bounded rationality. Given that all contracts are incomplete in the sense that all future contingencies cannot be dealt with in the contract, the possibility for opportunistic behaviour from at least one part is an unavoidable assumption. Oliver E. Williamson (1975) states that these two behavioural assumptions - bounded rationality and opportunistic behaviour - are essential when applying economic principles to the analysis of organisations.

The concept of bounded rationality relates to the idea that there are limitations to the knowledge available. Full details of the future are not possible, which inevitably means uncertainty will result. This uncertainty and limited information means that one is not able to write a complete contract. It does not matter how well-written a contract is, there will always be imperfections because there will be unimaginable situations that cannot be predicted and regulated (Milgrom and Roberts 1992).

The concept of opportunistic behaviour originates from the costs that arise when one party appears to be opportunistic because it imposes costs of inefficiency. Even the fact that there are risks of opportunistic behaviour by either party entails transaction costs because the risk leads to inefficiency in the transaction process.

Williamson (1981) states that transaction costs in the study of organisations can be applied on three levels. The first is the overall structure of the firm. This level discusses the operating parts and how they should relate to each other. The second level focuses on how the organisation is structured regarding which functions should be performed within the firm and which should be performed outside of it, and why. The third level concerns how human assets are organised within the firm.

\subsection{The incentive perspective}

The most popular model of incentive contracting that attempts to explain how individuals are motivated to perform is probably the classic principal-agent model. In this model, the principal cannot completely monitor the agent who might behave in an opportunistic manner at the expense of the principal (see for example Williamson, 1975; or Eisenhardt, 1989a). This opportunistic behaviour is described as the 'moral hazard problem'. In the real estate 
manger's daily work, the real estate owner has monitoring problems at the same time as the individual manager is responsible for large values. This means there are risks for opportunistic behaviour, for example, tasks that cannot be observed are neglected in favour of more observable or quantitative tasks.

For example, it may be more rational for the individual real estate manager (agent) to prioritise a new lease before making a service meeting with a current customer. This is because the owner (principal) would not usually see the manager's quality time with the customer. However, a new lease is directly quantified through fewer vacancies and higher rental income. To some extent, this behaviour can be regulated through different incentive schemes or contracts (Williamson 1981) depending on what the real estate owner (principal) wants the manger (agent) to prioritise. But as Azasu (2011) states, the real estate manager's work is multidimensional and consists of both tasks that are measurable and non-measurable yet just as important. This leaves us either with an incomplete contract or incentive scheme. A circumstance highlighted by Usher (2004) leads to the conclusion that relationships and contract formulations are the two critical success factors when outsourcing. In relation to this, Kadefors (2008) concludes that good relationships do compensate for incomplete contracts. This conclusion by Kadefors (2008) could also mitigate most of the risks for opportunistic behaviour outlined by Le Bon and Hughes (2009).

Gibler and Black (2004) add another circumstance to the incentive problem in the case where the real estate management service is outsourced. The firm hiring an outside service provider often has less knowledge regarding the service required. In this case, it is the service provider that possesses the specialist knowledge and a case of information asymmetry regarding the real estate managers (agents) tasks arises as well.

\section{Research design and methodology}

This article focuses on the results of an interview study. The aim of the study is to identify how the decision-maker in real estate-owning companies design incentives for the outsourced property management organisation in terms of securing information and maximising the amount of effort put in by the contracted company. This was studied by interviewing decision-makers and both the top-management representatives and the management teams in a facility management company. An understanding of the possible risk of post-contract transaction costs has been possible by investigating the decision-makers' views about what they prioritise and consider important for decision making. At the same time, this understanding is also increased by examining the management team's perception of the real estate owner's requirements and the management team's incentives to share different information and to perform different tasks.

\subsection{Data collection}

A selection of three real estate-owning companies and their facility management partner companies (in Sweden most commonly known as the 'service partner') was made for the study. This selection was made, as defined by Patton (2002) and Eisenhardt (1989), through a stratified purposeful sampling to ensure that three different facility management companies were included. Also, the selection was made to include real estate companies with a large enough real estate portfolio to have their own property management organisation, while at the same time, include different facility management companies. The real estate-owning companies in focus are all larger real estate owners with the possibility to have their own 
management organisation but have all actively chosen to outsource the property management organisation. The facility management companies all have the possibility to provide a full property management service. Therefore, the use of stratified purposeful sampling was the natural choice to ensure suitable representation of firms from both the real estate owner side and facility management side.

From each of the real estate-owning firms, the heads of property within the organisation were interviewed. This person is the real estate owner representative, and they are responsible for both the contract with the facility management firm and have the solid responsibility for the real estate portfolio within the real estate-owning firm. Figure 1 shows the organisational setting in relation to the interviews.

Owner company

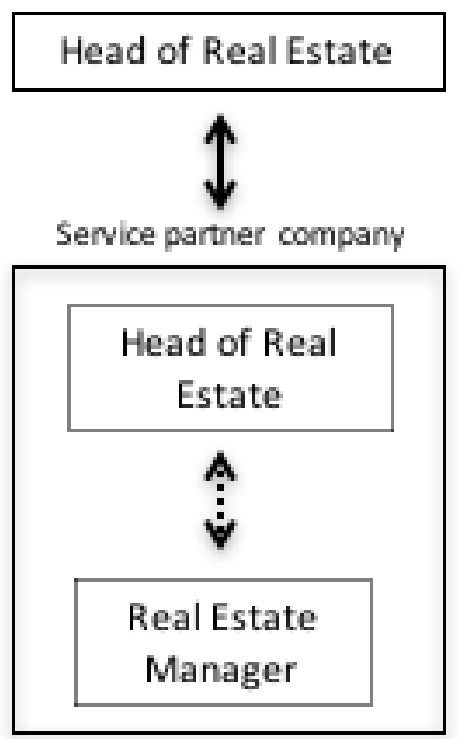

Figure 1. The organisational setting in relation to the interviews

As displayed in Figure 1, the heads of real estate from the two contracting partners were interviewed. Within the facility management firm, the management team for that portfolio was interviewed. In two of the cases, the real estate portfolios are so large that there are several teams for property management. In those two cases, only one team in each facility management company was included in the study. This was to ensure that the study described the incentives and working procedure with the same organisational and/or contractual settings.

Before the interview study was conducted, a test study was initiated with one real estate owning company and one facility management company. This was in order to be able to test the questioner and evaluate the structure of the interview study and to get a feeling of the field before conducting the interview study. In the end, these interviews were excluded from the study due to internal reorganisation within one of the companies which meant it was no longer possible to interview the entire property management team.

In the end, three decision-makers from real estate owning companies were interviewed and seven representatives from the three facility management firms were included. The design of the interview process was structured as semi-structured interviews (Kvale, 1995). 


\subsection{Interview themes}

The interviews were based on three-four themes; if the respondents did not mention a subject relating to any of the three themes, the respondents were asked to elaborate their answers by follow-up questions on the topic were asked. Please see Table 1 for the themes and follow-up questions.

Table 1

\begin{tabular}{|c|c|c|c|}
\hline \multicolumn{2}{|c|}{ Real estate owners } & \multicolumn{2}{|c|}{ Facility management organisations } \\
\hline Theme & Follow-up questions & Theme & Follow-up questions \\
\hline Organisational choice & $\begin{array}{l}\text { Why outsourcing? } \\
\text { How are the facility } \\
\text { management firm } \\
\text { chosen? } \\
\text { Contract length? } \\
\text { How can the contract be } \\
\text { terminated? }\end{array}$ & Role and function & $\begin{array}{l}\text { Work tasks } \\
\text { Size of team } \\
\text { Number of clients } \\
\text { (contracts) } \\
\text { Number of properties and } \\
\text { tenants } \\
\begin{array}{l}\text { Influence in the budget } \\
\text { process }\end{array}\end{array}$ \\
\hline Information sharing & $\begin{array}{l}\text { How are you informed? } \\
\text { What information is: } \\
\text { - Automatic? } \\
\text { - In writing, and how } \\
\text { often? } \\
\text { - Orally, and how often? }\end{array}$ & Information sharing & $\begin{array}{l}\text { What information is } \\
\text { reported to the real estate } \\
\text { owner, and how? } \\
\text { What is reported } \\
\text { internally, and how? } \\
\text { What automatic systems } \\
\text { do you use and do the real } \\
\text { estate owner have access? }\end{array}$ \\
\hline Regulations & $\begin{array}{l}\text { What is regulated in the } \\
\text { contract? } \\
\text { Bonuses for what? How } \\
\text { and why? } \\
\text { How are the providers } \\
\text { evaluated? }\end{array}$ & Regulations & $\begin{array}{l}\text { Responsibilities } \\
\text { Mandate } \\
\text { Bonuses } \\
\text { Knowledge about the } \\
\text { contract (with real estate } \\
\text { owner) }\end{array}$ \\
\hline Experiences & $\begin{array}{l}\text { Previous organisations } \\
\text { Previous } \\
\text { contracts/providers }\end{array}$ & Experiences & $\begin{array}{l}\text { How is the working } \\
\text { environment experienced? } \\
\text { Differences between } \\
\text { contracts } \\
\text { Previous } \\
\text { organisations/contracts }\end{array}$ \\
\hline
\end{tabular}

Before the interviews each respondent was informed regarding the four themes of the interview. The follow-up questions on the other hand were never displayed for the respondents. Only if the respondent did not get into this area when elaboration on the theme the specific follow-up question were asked. This to ensure not to influence the respondent in advance of the interview. By this procedure, the respondents first gave their story and only if they did not include everything I wanted to extract from the interviews, these follow-up questions were asked. This also gave the respondent the opportunity to make their own interpretation of the themes and telling their story.

\subsection{Data analysis}


To enable the sorting, interpreting, classifying and coding of the material, all the interviews were audio-recorded and the interviewer transcribed all of the material. This is a timeconsuming method, but it enables a better overview and understanding of the material. At the same time, it helps to secure the process and ensure the respondents are cited correctly. Taping and transcribing is also a working procedure that is considered essential when working with interviews (see for example Riessman, 1993).

For the analysis, each real estate owner and management team pairs were considered as a separate case. This enabled what Eisenhardt (1989b) labels 'cross-case patterns'. From there, structures and similarities were drawn. Using the framework of transaction costs for analysing the interview context in relation to incentives.

\section{Findings}

This section is divided into three parts where the role and function are first outlined before information sharing is displayed. Third, the incentives for effort and information sharing are outlined.

\subsection{Role and function}

The contract between the real estate owner and the facility management firm regulate both mandates and what tasks should be performed. However, the respondents report that even though the format might be the same, they experienced that no two contracts are the same in regard to mandate and task. The fact that the contract regulates mandates and tasks and that two contracts are not the same is something that the respondents highlighted as somewhat problematic. The property manager is to refer to the contract to know what to prioritise, especially as it is common that the property manager works for more than one real estate owner and therefore needs to know the specific terms and regulations in each contract when meeting or speaking with a tenant. One specific problem was addressed by a property manager who states that "colleagues sometimes think that they do great deals. But in the end, they come out prioritising the wrong tasks in the wrong contract".

All respondents exposed clear regulations of mandates in the contracts. They also have the same opinion regarding the limits within the budgets. All respondents in the facility management firms talked about levels up to three thousand Euros before having to make a formal written request to the real estate owner representative. Two of the respondents had previous experiences of contracts where the limit was even lower.

The influence in the budget process follows the same procedure in all three cases. It is the real estate owner who provides the framework and the basic prognosis for inflation and other macro-data. The real estate owner also provides a strategic document for each real estate property stating level of investment, yield and time horizon regarding continued ownership. Together, these documents act as the basis for the property manager to conduct a budget for each real estate property. The property manager is to create a one-year, three-year and fiveyear budget. However, all the real estate owner representatives and facility management representatives stated that the one-year budget is the most influential budget for the property manager because it is the one that regulates their financial limitations and thereby their everyday work. It is the head of property in the facility management firm's task to aggregate the budgets on the individual real estate level to contract level. Thereafter, a process where 
the real estate owner and the head of real estate in the facility management firm negotiate over the budget before it gets its final approval.

All respondents within the three facility management firms express some frustration over this back and forth movement of the budget proposal because it takes up a great deal of time. One of the heads of property stated that her property managers set their individual budget in September, and she hands in the aggregated budget in October to the real estate owner. However, they never have an approved budget before mid-December and needs hours of meetings both with the real estate owner and internal with property managers and technicians. Nevertheless, she states that there is no stone that has been left not turned over in determining whether there are any possible cost savings to be found.

In other words, the expenses are strictly controlled from the real estate owner side in different aspects and on different levels. First, the property manager makes a budget which is then "negotiated" and every possible cost saving is evaluated before finalising the budget. Second, if the tenant wants something done in the premises, the property manager can only decide on "investments" of maximum three thousand Euros before asking permission from the real estate owner. Third, the property manager is to report the financials on property level every month, both in writing and orally.

\subsection{Information sharing}

What types of information do the decision-makers request? What types of information are reported by the facility management company? Are there any differences between the information requested and the information reported? As mentioned, the contract details what tasks should be carried out, what information should be reported, and how. The reporting, as stipulated in the contract, is tied to the one-year budget and the strategic document for every real estate.

Every month, the property manager is to hand in a written report for every real estate, called the 'manager report' along with a follow-up on the budget. All financial outcomes for each real estate is commented on and all diversions from the budget are carefully explained and motivated. This manager report is followed up every month, which entails the individual property manager attending a follow-up meeting with the real estate owner representative. The main focus in these meetings is the financials and the leasing situation in the property manager's portfolio. Every quarter, this follow-up meeting becomes more extensive and the financials and leasing situation is discussed more in-depth on the individual real estate level in relation to the strategic document created by the real estate owner company. Both these monthly and quarterly follow-up meetings are documented, and the property manager from the facility management firm creates a written report afterwards.

All of the real estate owner representatives state that the focus in the reports are on the financials and on leasing. This is also confirmed by the facility management representatives. It is also clear that this structure of monthly reporting with follow-up meetings and more extensive follow-ups every quarter seems to be more or less standard in Sweden. The respondents never referred to any other type of structure and always referred to the structure as a certainty.

\subsection{Incentives for effort and information sharing}


All three cases in this paper show the same thing - that monetary bonuses exist on a businessto-business level but not on the property manager level.

All contracts have the opportunity for a bonus on the business-to-business level for new rentals. Furthermore, on a business-to-business level, two of the contracts have a more subjective bonus. The real estate owner is free to decide on the bonus, and it is not regulated in the contract. The senior managers in the facility management firms were fully aware of its existence. However, the bonus would only be paid if the real estate owner thought that the facility management firm exceeded expectations. What it means to "exceed expectations" and what it relates to as well as the size of the bonus is not clear, as there are no criteria for this bonus. One of the respondents from the service provider companies stated, "There are no clear criteria, but there is a possibility”.

None of the facility management firms have any bonuses within the firm, and the senior managers in the facility management firms do not regard bonuses as a motivating factor for their co-workers. However, one of the senior managers stated that they had started to investigate the question in the firm; however, not as a motivating factor but rather as a way to attract younger co-workers who they view as having a more competitive nature and are not satisfied with only the possibility of a future promotion. A factor for this is that all of the facility management firms have an internal requirement policy where all vacancies are to be advertised internally first before going public.

When it comes to incentives for information sharing, there is none that goes beyond what the contract stipulates must be reported to the real estate owner every month. It was even the case that the real estate representatives did not understand the question. One said, "I don't understand. It is regulated in the contract that they are to report the financials every month. We do not need any incentives!”

\section{Discussions}

There is a tight cost control in the contracts stipulating that the facility management firm must report the finances every month. This tight cost control is also present in the budget process where, as one respondent stated, "There is no brick that has not been turned or flipped over to see if there is any possible cost saving to be done". At the same time, no monetary incentives are available on individual level only on the business-to-business level, and on this level only for new leases - in other words, incentives for increasing the cash-flow and a strict control over all expenses. This could lead to the same circumstance as reported by Song et al. (2013) who concludes that frontline workers in the contracted firms demonstrate a lower level of service.

However, no monetary incentives are offered to the individual property manager to perform or share information. This is somewhat awkward, given that a complete contract is impossible. This could present the risk that the real estate owner would receive a backlash as described by Le Bon and Hughes (2009) regarding the uncertainty of performance leading to opportunistic behaviour from the service providing firm. Is it that the real estate owner is over confident of the individual property manager's interest in keeping them informed or are they simply not interested in any information except the financials reported in the written report provided every month? This seems odd, given that they do not have a local presence and to do business they ought to be interested in this kind of information. In particular, after considering the old adage that all business is local business, this lack of interest regarding anything other 
than numbers is somewhat strange and may lead to information asymmetry, as Gibler and Black (2004) point out, but with the extension of market sensitivity.

Also, the fact that there are no monetary bonuses for making an effort or performance renders a big question mark. The contract can neither stipulate the individual to out-perform nor can it regulate all work tasks; instead, confidence in the property manager's ability to have the right priorities seems to be high from the real estate owner's side. A circumstance that might add to the real estate owner's confidence is the rather short contracts (often one year) and the fact that there is only one month of notice before termination if the service providing firm does not stick to the budget or fails in reporting. Perhaps these factors work as incentives for the property manager to perform. This is somewhat confirmed by one of the respondent property managers who states that one thing that he likes with his work is that he always must perform and outperform his colleagues in the in-house real estate firms; otherwise, they risk losing the contract and he risks losing his job. A change of facility management firm which depends on the rigours of documentation is relatively inexpensive for the real estate owner to make in terms of transaction costs.

However, although there are no monetary bonuses on the management level, there are bonuses for new leases on the company level. This might render (un)official internal policies within the facility management company to prioritise leasing matters before matters regarding retention. There might be this kind of bias in the service relation between the real estate owning company and the performance from the property manager, given that there are no bonuses for contract renewal, only for new contracts.

\section{Conclusions}

Bonuses are only given for the facility management company when making a new lease and are not given on the management level. This might lead to a bias in terms of prioritising leasing before customer attention. However, this can be mitigated by constructing an equal bonus for the facility management company by introducing a bonus for a contract renewal as well. This would be an incentive for the property manager to work with a more long-term focus. The short contracts mean she knows that in a year or two she will be required to negotiate a contract renewal with the new customer.

To summarise, there are clear regulations in the contracts between the real estate owner and the facility management firm in the contracts regarding tasks, mandates, information sharing, and the form for reporting. These regulations are clearly delegated to the property manager. The property manager is also clearly aware that the contract is up for renewal every year. Overall, in regard to the insecurity regarding contract renewal, motivation is more by fear than the opposite, both for the property manager and the facility management company.

\section{Implication for further research}

Further research Ecomparing how customer orientation is carried out and how the service is perceived from a customer perspective fould be of interest for further studyis needed. This would provide a new perspective on the topic of the outsourcing model. Is it possible to find the same pattern as one finds in the Swedish setting (Song et al., 2013), where we can observe rigorous processes and heavy administrative tasks for the property manager? 
Further research is also required to analyse how the new generation, now entering the job market, is motivated and what creates incentives for them to perform. This will also provide an insight to how future contracts might be designed. It would also be of great interest to conduct a study where the bureaucracy, documentation and meetings are measured to determine how much time the facility management firm spends on these types of tasks instead of taking care of the tenants and the properties. This could be compared to the benefits of a rigid process and well doemmented properties, and thus the transaction costs in the different organisational settings can be estimated.

\section{References}

Abdullah, Shardy, Arman, Abdul, Razak, and Abd, Hamid, Kadir, Pakir. (2011), The characteristics of real estate assets management practice in the Malaysian Federal Government, Journal of Corporate Real Estate, Vol. 13 No. 1, pp. 16-35.

Ali, Zaiton, Stanley, McGreal, Alistair, Adair, James R. Webb. (2008), Corporate Real estate strategy: A conceptual overview. Journal of real estate literature. Vol 16 No 1 pp 3-21.

Ansoff, Igor. (1984), Strategic management Palgrave Macmillan Basingtoke

Agerwal, Sumit, and Hauswald, Robert. (2010), Distance and Private Information in Lending, Review of Financial Studies Vol. 23, No. 7, pp. 27757-2788.

Azasu, Samuel. (2011), Ownership and size as predictors of incentive plans within Swedish real estate firms, Property Management, Vol. 29, No. 5, pp. 454-467.

Caves, Richard, E. (1980), Industrial organization, Corporate Strategy and Structure, Journal of Economics Literature, Vol. 18, No. 1, pp. 64-92

Coase, Ronald, H. (1937), The nature of the Firm, Economica, No. 4, pp. 386-405

Edwards, Victoria, and Ellison, Louise, (2004), Corporate property management. Blackwell Science Ltd., Oxford UK.

Eisenhardt, Kathleen. (1989a), Agency Theory: An Assessment and Review, Academy of management review, Vol. 14. No 4, pp. 532-550.

Eisenhardt, Kathleen. (1989b), Building theories from case study research. Academy of management review, Vol. 14. No 1, pp. 57-74.

Gibler, Karen, M., Black, Roy, T. (2004), Agency risks in Outsourcing Corporate Real Estate Functions, The journal of Real Estate Research, Vol. 26, No. 2, pp. 137-160.

Hewlett, Charles, A. (1999), Strategic planning for real estate companies. Journal of property management Vol 64 No 1 pp26-29

Hätönen, Jussi, and Eriksson, Taina. (2009), 30+ years of research and practice of outsourcing, Journal of International Management. No. 15, pp. 132-155. 
Johnson, Gerry, Whittington, Richard, and Scholes, Kevan. (2011), Exploring Strategy, 19th ed., Prentice HallHarlow.

Kadefors, Anna. (2008), Contracting in FM: collaboration, coordination and control, Journal of Facilities Management, Vol. 6, No. 3, pp. 178-188.

Kvale, Steinar. (1995), Den kvalitative forskningsintervjun. Studentlitteratur, Lund

Lawrence, Chin, and Poh, Lam, Khee. (1999). Implementing quality in property management -The case of Singapore. Property Management Vol. 17 No. 4 pp. 310-316.

Le Bon, Joël, and Hughes, Douglas, E. (2009), The dilemma of outsourcing customer service and care: Research propositions from a transaction cost perspective. Industrial Marketing Management, vol. 38, Iss. 4, pp. 404-410.

Lundström, Stellan. (2011), kap. 27 Fastighetsföretagande, i Institutet för värdering av fastigheter och ASPECT, Fastighetsekonomisk analys och fastighetsrätt Fastighetsnomenklatur, 11:e upplagan.

Milgrom, Paul, and Roberts, John. (1992), Economics, Organisation and Management, Prentice Hall, Upper Saddle River, New Jersey.

Morrison, Allen, J., and Roth, Kendall. (1992), A Taxonomy of business-level strategies in global industries, Strategic Management Journal, Vol. 13, No. 6, pp. 399-417.

Patton, Michael, Quinn. (2002), Qualitative research \& Evaluation methods 3ed. Sage Thousand Oaks

Penrose, Edith. (1959), The Theory of the Growth of the Firm, 4th ed. Oxford, University press.

Porter, Michael. (1981), The contribution of industrial organization to strategic management. The academy of management review, Vol. 6, No. 4, pp. 609-620.

Riessman, Catherine, Kohler. (1993), Narrative analysis. Qualitative research methods series 30 SAGE University paper.

Sandberg, Nils-Erik. (red), Fagerfjäll Roland, Lundström Stellan, Pettersson Karl-Henrik, Tson Söderström Hans, Åsbrink Erik. (2005), Vad kan vi lära av kraschen? Bank- och fastighetskrisen 1990-1993. SNS förlag. Stockholm.

Song, Chanhoo., Lee, Sunhee, and Lee, Euehun. (2013), Outsourcing frontline functions and implications on customer-oriented behaviours: A case of a telecommunications company and its partners in South Korea. Journal of Management \& Organisation, Vol. 19, No. 2, pp. 210223.

Stein, Jeremy, C. (2002), Information Production and Capital Allocation: Decentralized versus Hierarchical Firms, Journal of Finance, Vol. 57, No. 5, pp. 1891-1921. 
Teece, David, J. (2010), Business models, business strategy and innovation. Long range planning Vol 43 pp 172-194.

Usher, Neil. (2004), Outsource or in-house facilities management: The pros and cons, Journal of Facilities Management. Vol .2 No. 4, pp351-359.

Ventovuori, Tomi. (2007), Analysis of supply models and FM service market trends in Finland -Implications on sourcing decision-making, Journal of Facilities Management, Vol. 5, No. 1, pp. 37-48.

Wernerfelt, Birger. (1984), A Resource -Based View of the Firm, Strategic Management Journal, Vol. 5, No. 2, pp. 171-178.

Williamson, Oliver, E., (1981), The Economics of Organization: The Transaction Cost Approach, American Journal of Sociology. Vol. 87, No. 3, pp. 548-577.

Williamson, Oliver, E., (1975), Markets and Hierarchies Analysis and Antitrust Implications. Free Press cop. New York.

Zuniga, Fernando de. (2005), Corporate real estate outsourcing contracts and their embedded flexibility, Journal of Corporate Real Estate, Vol. 7, No. 4, pp. 306-325. 